\title{
ТЕОРЕТИЧНІ ЗАСАДИ ДОСЛІДЖЕННЯ ЕМОЦІЙНОЇ СТІЙКОСТІ
}

\begin{abstract}
Емоційну стійкість визначено як інтегративну властивість особистості, що забезпечується збалансованою динамічною взаємодією окремих підсистем циклічної багаторівневої функціональної системи регуляції поведінки і зумовлює ефективність управління та досягнення мети в значущих емоціогенних ситуаціях. Проаналізовано роль емоційного переживання в конструюванні образу потребового майбутнього, а також його вплив на мотивацію та поведінку особистості. Проведено дослідження впливу різних груп емоцій на емоційну стійкість, для чого було використано п'ятикомпонентну типологію базальних емоцій. Встановлено, що емоційна стійкість залежить від загального співвідношення параметрів досвіду і видів діяльності, у яких цей досвід формувався, а віднесення того чи іншого індивіда до певного якісного типу емоційності не екстраполюється на рівень його емоційної стійкості. 3'ясовано, що емоційна стійкість зумовлює вибір відповідного плану дії (образ потребового майбутнього) та особливості безпосередньої його реалізації (образ виконання) і детермінована як досвідом 3 включеними в нього ядерними уявленнями, так і первинними (поверховими) уявленнями - образами діяльності (причому в конкретній ситуації один із чинників зазвичай переважає). Зроблено висновок, що емоційна стійкість однозначно не корелює з інтенсивністю негативних переживань, хоча частка останніх дещо вища в групі емоційно нестійких досліджуваних.

Ключові слова: активність, емоційна стійкість, реабілітаційні заходи, образ потребового майбутнього, образ виконання.
\end{abstract}

Постановка проблеми. Феномен емоційної стійкості (ЕС) досліджували психологи різних країн (особливо активно - 3 кінця 60-х до середини 90-х років минулого століття) переважно в контексті спор-ту вищих досягнень [1; 3-16 та ін.]. Сьогодні, у зв’язку з агресією Росії проти України, проблема емоціональної стійкості особистості постає в новому контексті - вирішення завдань соціально-психологічної реабілітації бійців, членів їхніх родин, мирних мешканців у зоні бойових дій та переселенців.

Mema cmammi: узагальнення сучасних теоретичних концепцій емоційної стійкості та обгрунтування власного підходу до дослідження цього феномену.

Аналіз останніх досліджень та публікацій. Сучасні розвідки [1-16 та ін.], присвячені проблемі емоційної стійкості, можна об'єднати в три напрями:

1) дослідження емоційної стійкості в контексті забезпечення належного рівня реалізації діяльності в екстремальних та особливих умовах; 
2) дослідження в галузі медицини (психосоматика і психосоматичні розлади);

3) дослідження особливостей впливу емоцій на соматику, діяльність і поведінку особистості.

У соціально-психологічних дослідженнях емоційної стійкості можна виокремити дві проблемні зони. Перша, умовно позначена нами як теоретична, охоплює проблематику соціально-психологічних механізмів емоційної стійкості та детермінант зростання емоційної нестабільності соціуму. На особливу увагу заслуговує системний аналіз емоційної нестійкості (ЕН) як соціально-психологічної проблеми і як соціального ресурсу впливу (зокрема дослідження процесів, що відбуваються в соціумі в умовах зростання частки ЕН, та мобілізаційного потенціалу ЕН лідерів думок). Друга зона - прикладна проблематика це насамперед брак апаратурних методів та методик, за допомогою яких можна було б верифікувати результати якісних досліджень, а також невизначеність показників та критеріїв оцінювання емоційної стійкості на різних рівнях ії̈ прояву.

Усе це зумовлює низький рівень надійності діагностики, оскільки дослідник не має змоги чітко визначити, навмисне чи ненавмисне приховується чи-то викривлюється респондентом значуща для планування реабілітаційних заходів інформація, чому вона приховується тощо. Також утруднюється завдання прийняття рішення про надання групової чи індивідуальної допомоги, оскільки не з'ясовано, за якими ознаками має формуватися група для надання конкретної допомоги, як здійснювати впровадження комплексу заходів щодо розвитку ЕС в групах ризику і т. ін.

Аналіз досліджень, присвячених проблемі емоційної стійкості, показав, що наразі немає єдності як у трактуванні підходів до ії̈ вивчення, так і у визначенні самого поняття емоційної стійкості (див. огляди в [1; 2; 9; 13-15]) та ін.]). Не вдаючись до полеміки, у цьому дослідженні під емоційною стійкістю ми будемо розуміти інтегративну властивість особистості, яка забезпечується збалансованою динамічною взаємодією окремих підсистем циклічної багаторівневої функціональної системи регуляції поведінки і зумовлює ефек-тивність управління та досягнення мети в значущих емоціогенних ситуаціях.

Щоб означити проблемне поле досліджень ЕС, слід визначитися щодо низки категорій, які почасти використовують як синонімічні (стрес, нейротизм, стресостійкість емоційна нестабільність). Термін стрес у наукову термінологію ввів Г. Сельє, зробивши таким чином внесок у теорію загального адаптаційного синдрому, який забезпечує пристосування організму до змінюваних умов середовища. При цьому поняття "стрес" автор розумів як неспецифічну відповідь організму на вплив подразника. Г. Сельє розмежовував поняття “стрес" і “дистрес". 
Стрес, на відміну від дистресу, є корисним та приводить до адаптації, а дистрес - до різноманітних психосоматичних захворювань. Л. О. КитаєвСмик у загальному адаптаційному синдромі виділив такі субсиндроми: емоційно-поведінковий, вегетативний, когнітивний, соціально-психологічний. Р. Лазарус описував фізіологічний i психічний стрес. А. Б. Леонова запропонувала три основні підходи до аналізу професійного стресу: екологічний (взаємодія з навколишнім середовищем); транзактний (індивідуально-пристосувальна реакція людини); регуляторний (особливий клас станів, що відбиває механізм регуляції діяльності в утруднених ситуаціях). Т. Кокс, А. Макікангас та У. Кіннунен, Г. Г. Аракелова, А. Б. Леонова, О. М. Кокун та ін. по-різному оцінюють стрес (див. огляд у [6]).

Виклад основного матеріалу дослідження. Наші дослідження показали, що стрес неоднозначно впливає на кінцевий результат. Найвищі показники в діяльності виконавці отримують за умови дії стресу середньої сили, а вона для кожної особистості має свої значення і значною мірою залежить від іiі майстерності, психофізіологічного стану, вміння комунікувати тощо.

Під стресостійкістю зазвичай розуміють здатність особистості адекватно реагувати на емоціогенні події, а в разі необхідності - мобілізувати свою психіку і діяти розсудливо.

Нейротизм пов'язують 3 емоційною збудливістю. Високий рівень нейротизму свідчить про знижений поріг активації лімбічної системи (у такому трактуванні емоційна нестабільність - це реактивність у відповідь на події, що відбуваються у внутрішньому середовищі організму, на коливання організмічних потреб і станів). Особи з високим рівнем нейротизму вирізняються лабільністю, гіперактивністю та повільним поверненням до вихідного стану після емоційних стресів. Вважають, що високий рівень нейротизму призводить до виникнення невротичних розладів, хоча його високі показники не обов'язково пов'язані з неврозами.

У сучасних дослідженнях емоційної стійкості можна виокремити два парадигмальних підходи: активності та реактивності. Спроби при інтерпретації поведінки та діяльності замінити проблему “активністьреактивність" проблемою зіставлення внутрішніх і зовнішніх детермінант поведінки і довести, що згадані підходи кардинально не відрізняються між собою, $є$ нічим іншим, як намаганням прихильників реактивної парадигми заретушувати принципово протилежні методологічні позиції. Основна відмінність між парадигмами "реактивності” й “активності” виявляється в розумінні того, де на часовій шкалі розміщена детермінанта поточної поведінки - у минулому чи майбутньому. Реактивна форма реагування передбачає лінійну форму розгортання послідовності подій від минулого - теперішнього до майбутнього. Неважко спрогнозувати наслідки діяльності психотерапевта, який вдається до 
реабілітаційних технологій постійного повернення респондента у минуле. Натомість психотерапевт, який працює в парадигмі активності (майбутнє - теперішнє - минуле), спрямовує респондента в майбутнє, орієнтує на формування образу потребового майбутнього, мотивуючи його до самостійного планування, досягання і коригування проміжних результатів. Відтак у парадигмі активності емоційну стійкість розглядають як таку, що детермінується спрямованістю в майбутнє. Сам по собі досягнутий результат і його оцінка особистістю $є$ минулим, тому він не може спонукати їі до активності. Спираючись на результати власних досліджень, можемо констатувати, що системотвірним фактором $\epsilon$ не досягнутий результат, а розбіжність між досягнутим результатом та образом потребового майбутнього. Якщо параметри цієї розбіжності задовольняють особистість, то вона припиняє пошуки нових прийомів досягнення потребового майбутнього і концентрує увагу на трансформації набутого досвіду відповідно до ситуації, яка пред'являється. Коли ж величина розбіжності не задовольняє ії очікування, тоді вона продовжує пошук шляхів досягнення бажаного результату, а це і $\epsilon$ спонука до розвитку всіх функціональних систем та зміни поведінки особистості в цілому. Спрямованою в майбутне може бути тільки оцінка особистістю міри розбіжності між образом потребового майбутнього і досягнутим результатом. Ось чому при плануванні і проведенні реабілітаційних заходів нам видається більш продуктивним спиратися на парадигму активності. У контексті нашого дослідження ми зосередимо свою увагу на когнітивних аспектах емоційної поведінки та особливостях суто ідеального емоційного переживання.

На основі аналізу даних $[1-3 ; 9 ; 14 ; 15]$, а також власних досліджень [5-7] можемо констатувати, що найбільш важливим, ключовим етапом, який визначає розвиток поведінки та ії емоційне забарвлення, можна вважати означення мети, котра зумовлена інтенсивністю й тривалістю емоційних станів, асоційованих з об'єктом уваги. У такому вигляді мета представлена в смисловій структурі і завданні дії двома типами образів: власне мети (образ потребового майбутнього, образи виконання дії, діяльності, поведінки) та способів, за допомогою яких досягаються цілі (конкретні образи виконання, навички, автоматизми тощо). При цьому виокремлення мети пов'язується з операцією прийняття рішення, на яку впливають як провідні, так і ситуативні емоції. Якість і специфіка провідного емоційного переживання пов'язані 3 типом та особливостями потреби, яка його породила. Ситуативні емоції виникають у процесі дій, які виконуються щодо мети і є наслідком зіставлення досягнутого результату з образом потребового майбутнього та внесення відповідних корекцій. У разі розбіжності виникають емоційні переживання з від'ємним знаком, у разі збігу - позитивні емоції та емоційні стани. Цілеспрямована поведінка - пошук цільового об'єкта, 
завдяки якому задовольняється потреба, котра спонукається як негативними, так і позитивними емоційними переживаннями, а також уявленнями про ці зафіксовані пам’яттю стани.

Постійне зіставлення результатів діяльності з образом потребового майбутнього, образами виконання спонукає особистість до оновлення змісту самого програмування й обумовлює цілеспрямованість діяльності, а це і є однією з умов набуття життєвого особистісного досвіду. Допомагає цьому процесу орієнтаційно-пошукова діяльність, завдяки якій стає можливим більш ретельний аналіз ситуації та успішне видобування інформації з пам'яті. Орієнтаційна діяльність характеризується не тільки багаторазовою зміною змісту, який відображається, визначенням нових цілей, а й перебиранням окремих варіантів поведінки для прогнозування очікуваного результату. Це перебирання може спиратися як на пробні дії, так і на такі, що виконуються повністю у внутрішньому плані. Виконання такої дії приводить до змін стимуляції, яка відкриває нові можливості для дій; це, відповідно, дає змогу вибрати 3-поміж багатьох із них таку, що найбільшою мірою підходить, та апробувати іiі. Таке циклічне розгортання ієрархічно більш загальних цілей на більш дрібні може відбуватися декілька разів поспіль, доки вся майбутня діяльність не постане перед особистістю у вигляді логічно вивіреної низки цілей (смислової структури, завдань дії), спосіб досягнення яких уже відомий. При цьому уточнення цілей може здійснюватися і в ході вже розпочатої дії, діяльності, поведінки, якщо дозволяє дефіцит часу, у якому ця діяльність відбувається. Таким чином, конструювання мети відповідно до нових умов стає свого роду ресурсом реабілітаційних заходів.

Під час планування та реалізації реабілітаційних заходів перед психотерапевтом нерідко постає проблема формування відповідної мотивації та чіткого усвідомлення респондентом мети цих заходів. Постановка суб'єктом мети є фактично засобом структурування мотивації. Отож емоція - це відображення міри та ймовірності задоволення потреби на цю мить у цій ситуації. Емоції, як і мотивація, пов’язані 3 механізмами контролю ефективності поведінки і виражають співвідношення між сприйманням і дією. Центральною інстанцією, що забезпечує механізми побудови, регуляції та управління діями, діяльністю, поведінкою, є психічний образ, який містить найважливішу інформацію, необхідну для побудови, регуляції поведінки та управління нею; відображає потреби, цілі, мотиви та емоції, можливості їх зміни, а також власне дії, здатні ці зміни забезпечити. Для того щоб ця можливість була реалізована, необхідна внутрішня активність суб'єкта.

Розглядаючи емоційну стійкість, не можна обійти сучасні погляди на базальні емоції $[1 ; 4 ; 8-15$ та ін.]. Аналіз цих робіт, а також власних досліджень [5-7; 16] дає змогу виділити n'ять груп базальних емоцій: 
сум, страх, гнів, радість; п'яту групу утворюють емоції, які супроводжують психофізіологічні зміни, що відбуваються в організмі.

Розгляньмо відтак ці п'ять груп емоційних переживань більш детально (результати отримано в ході досліджень ЕС спортсменів високої кваліфікації).

Перша група - сум: туга, пригніченість, смуток, почуття суму, засмученість, приголомшеність, зневіра, страждання, відчуття безпросвітності, відчуття безнадійності, занепад духу, відчай, в'ялість, байдужість, депресія.

Друга група - страх: переляк, жах, тривога, нерозуміння, неспокій, заклопотаність, побоювання, почуття тривоги, сором'язливість, невпевненість, хвилювання, збентеження, несміливість, обережність, сумнів, розгубленість, відчуття неуспіху, подив.

Третя група - гнів: лють, злість, обурення, роздратування, невдоволеність, досада, ворожість, огида, презирство.

Четверта група - padicmb: тріумфування, окриленість, азарт, захват, запал, здогадка, почуття успіху, захопленість, упевненість, гордість.

П'ята група - психофізіологічні зміни в організмі: збудження, напруженість, передстартова лихоманка, стан бойової готовності, стан мобілізаційної готовності, задоволеність результатом, невизначеність щодо оцінки результату, розчарування, фрустрація, апатія.

Більшість досліджуваних характеризують як інтенсивні емоції “страх”, “боязнь”, “жах”, тоді як “невпевненість”, “сумніви” і “тривогу” відносять до слабких переживань. Проміжну групу склали всі інші емоційні прояви. Аналогічні закономірності отримано також і за іншими емоційними модальностями (тривалість, яскравість тощо).

Характер усіх виявлених зв'язків свідчить про те, що чим вищі індивідуальні оцінки одного емоційного показника, тим вищі оцінки за іншими емоційними характеристиками, які стосуються до цієї ж самої модальності, і навпаки. Гіпотетично можна припустити, що емоційні прояви, які належать до п'ятої групи, можуть бути пов'язані, за певних обставин (наприклад, під час тривалого та інтенсивного переживання емоціiі), з одним або декількома із чотирьох груп емоційних переживань.

Результати аналізу співвідношення емоційної стійкості з виявленими якісними і динамічними характеристиками переживань свідчать про те, що ЕС не можна ототожнювати з будь-яким окремим емоційним проявом. Багато в чому рівень ЕС залежить від загального співвідношення параметрів, досвіду і виду діяльності, в якій цей досвід формувався. Отже, належність тієї чи іншої особистості до певного якісного

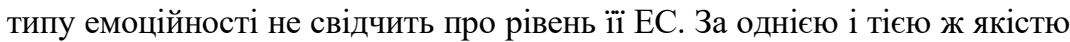
емоції (будь то радість, гнів або тривога) може стояти практично безліч предметних зв'язків (відносин), які по-різному характеризують суб'єкта діяльності. За результатами аналізу емпіричного матеріалу зроблено 
висновок про те, що ЕС може бути детермінована: а) переважно досвідом з включеними в нього ядерними уявленнями; б) переважно первинними (поверховими) уявленнями - образами діяльності. У кожному випадку досвід і первинні уявлення доповнюють одне одного. ЕС однозначно не корелює з інтенсивністю негативних переживань, хоча частка останніх дещо вища в групі емоційно нестійких осіб.

ЕС зумовлює вибір відповідного плану дії (образ потребового майбутнього) та особливості безпосередньої його реалізації (образ виконання).

Використання аудіо-, відео-, аромостимуляції з паралельною фіксацією емоційного напруження за допомогою реєстрації шкірогальванічної реакції (ШГР), фотоплетизми, дихання тощо [5; 16] дало змогу встановити, що емоційні переживання в одних випадках випереджають вербальні та уявно-кінематичні стимули (ідеомоторне тренування, перегляд аудіовідеозапису власних реакцій, поведінки), а в інших запізнюються щодо них. Це свідчить про наявність антиципаційної сигналізації або “презентації” когнітивних відносин і закріплення, емоційного “санкціонування" або констатації сформованих образів поведінки. Слід також зазначити, що емоційно стійкі (ЕС), як і емоційно нестійкі (ЕН) досліджувані переживають як негативні, так і позитивні емоції. При цьому інтенсивність деяких негативних переживань дещо вища в групі нестійких.

3 розвитком ЕС особистість стає більш емоційною, точніше емоційно різноманітною. Якщо розділяти емоції на нижчі і вищі, то різноманітність переживань в емоційно стійких досліджуваних спостерігається якраз щодо другої групи емоцій (страх), пов'язаних 3 діяльністю, свідомістю, мисленням. Зауважимо, що рівень ЕС (високий, середній чи низький) залежить від емоційного досвіду особистості, а належність особистості до певного якісного типу емоційності не обов'язково вказує на рівень іiі ЕС.

Висновки. Емоційну стійкість визначено як інтегративну властивість особистості, що забезпечується збалансованою динамічною взаємодією окремих підсистем циклічної багаторівневої функціональної системи регуляції поведінки і зумовлює ефективність управління та досягнення мети в значущих емоціогенних ситуаціях. Опертя на парадигму активності визнано більш продуктивним для прогнозування подальшої поведінки та змін у психіці респондента на основі виявлення розбіжностей між образом потребового майбутнього і досягнутим результатом.

Застосування апаратурних методик (наприклад, сучасного діагностичного комплексу на кшталт “ДИК-01-01”) дає змогу комплексно оцінювати індивідуальні особливості пристосувальних функцій досліджуваного та визначати стратегію і тактику як індивідуальних, так i 
групових реабілітаційних заходів, спрямованих на розвиток емоційної стійкості. Між структурою діяльності і будовою мотиваційно-емоційної сфери особистості існують відношення взаємної відповідності; у межах функціональної системи ієрархія мотивів співвідноситься з ієрархією цілей відповідно до завдань, які вирішуються особистістю.

ЕС визначає специфіку психічного образу, який, відповідно, зумовлює побудову, регуляцію діяльності та управління діями, поведінкою особистості. ЕС залежить від загального співвідношення параметрів, досвіду і виду діяльності, в якій цей досвід формувався, а віднесення того чи іншого індивіда до певного якісного типу емоційності не екстраполюється на рівень його ЕС. ЕС може бути детермінована: a) переважно досвідом 3 включеними в нього ядерними уявленнями; б) переважно первинними (поверховими) уявленнями - образами діяльності. У конкретній ситуації досвід і первинні уявлення доповнюють одне одного. ЕС однозначно не корелює 3 інтенсивністю негативних переживань, хоча частка останніх дещо вища в групі емоційно нестійких досліджуваних.

\section{Лimepamyра}

1. Аболин Л. М. Психологические механизмы эмоциональной устойчивости человека / Л. М. Аболин. - Казань : Изд-во Казан. ун-та, 1987. - 262 с.

2. Аршава I. Ф. Аспекти імпліцитної діагностики емоційної стійкості людини : монографія / І. Ф. Аршава, Е. Л. Носенко. - Дніпропетровськ : Вид-во Дніпропетров. нац. ун-ту, 2008. - 468 с.

3. Вилюнас В. К. Психологические механизмы мотивации человека / В. К. Вилюнас. - Москва : МГУ, 1990. - 288 с.

4. Изард К. Психология эмоций / К. Изард ; [пер. с англ. А. Татлыбаева]. Санкт-Петербург : Питер, 1999. - 464 с.

5. Малхазов О.Р. Концептуальні підходи до вирішення проблеми використання приладів реєстрації емоційної напруги при профвідборі працівників ОВС України / О. Р. Малхазов // Збірник наукових праць. Київ : КІВС, 2002. - С. 132-139.

6. Малхазов О. Р. Психологія праці (навчальний посібник) / О. Р. Малхазов. Київ : Центр навч. літ., $2010 .-180$ с.

7. Малхазов О.Р. Психологія та психофізіологія управління руховою діяльністю : [монографія] / О. Р. Малхазов. - Київ : Євролінія, 2002. - 320 с.

8. Плахтиенко В. А. Надежность в спорте / В. А. Плахтиенко, Ю. М. Блудов. Москва : ФиС, 1983. - 176 с.

9. Рейковский Я. Экспериментальная психология эмоций : [пер. с пол.] / Я. Рейковский. - Москва : Прогресс, 1979. - 325 с.

10. Симонов П. В. Эмоциональный мозг / П. В. Симонов. - Москва : Наука, 1981. $-216 \mathrm{c}$.

11. Черникова О.А. Исследование эмоциональной устойчивости как важнейшего показателя психологической подготовленности спортсмена к соревнованиям / О.А. Черникова // Психологические вопросы спортивной тренировки. - Москва : Физкультура и спорт, 1967. - С. 3-13. 
12. Экман П. Психология лжи / П. Экман. - Санкт-Петербург : Питер, 2003. $270 \mathrm{c}$.

13. Arnold M. B. Stress and emotion / M. B. Arnold // Psychological stress / ed. by Appley M. H. and Trumbull R. - New York: Appletin-Century Crofts, 1967. P. 123-140.

14. Kang S.-M. Socialand emotional intelligence: Starting a conversation bout their similarities and differences / S.-M. Kang, J. D. Day, N. M. Meara // Emotional intelligence: An international handbook / R. Schulze, R. D. Roberts (eds). Cambridge, MA : Hogrefe, 2005. - P. 91-105.

15. Malkhazov A. New solutions to the problem of the psychological support of an operator's safety / A. Malkhazov // Proceedings of the Second World Congress "Aviation in the XXI - st century" "Safety in aviation and space technology". Kyiv, Ukraine, NAU. - Kyiv, 2008. - P. 6.28-6.32.

16. Micro-valences: Perceiving affective valence in everyday objects / S. Lebrecht, M. Bar, B. L. Feldman, M. J. Tarr // Frontiers in Psychology. - 2012. - № 3. P. 107.

\section{References}

1. Abolin, L. M. (1982). Psikhologicheskiye mekhanizmy emotsionalnoy ustoychivosti cheloveka [Psychological mechanisms of emotional stability of a person]. Kazan: Publ. Kazan State University (rus).

2. Arshava, I. F., \& Nosenko, E. L. (2008). Aspekty implitsytnoi diahnostyky emotsiinoi stiikosti liudyny [Aspects of implicit diagnostics of emotional stability of a person]. Dnipropetrovsk (ukr).

3. Vilyunas, V. K. (1990). Psikhologicheskiye mekhanizmy motivatsii cheloveka [Psychological mechanisms of human motivation]. Moscow (rus).

4. Izard, K. (1999). Psikhologiya emotsiy [Human emotions]. Transl. by A. Tatlybaeva. St. Petersburg: Piter Publ. (rus).

5. Malkhazov, O. R. (2002). Kontseptualni pidkhody do vyrishennia problemy vykorystannia pryladiv reiestratsii emotsiinoi napruhy pry profvidbori pratsivnykiv OVS Ukrainy [Conceptual approaches to solving the problem of use of devices for registration of emotional stress during the professional election of officers of the Ministry of Internal Affairs of Ukraine]. Zbirnyk naukovykh prats [A collection of Scientific works]. Kyiv, pp. 132-139 (ukr).

6. Malkhazov, O. R. (2010). Psykholohiya pratsi (navchalnyi posibnyk) [Psychology of labor (textbook)]. Kyiv (ukr).

7. Malkhazov, O. R. (2002). Psykholohiia ta psykhofiziolohiia upravlinnia rukhovoiu diialnistiu [Psychology and psychophysiology of motor activity management]. Kyiv: Yevroliniia Publ. (ukr).

8. Plakhtiyenko, V. A. (1983). Nadezhnost v sporte [Reliability in sports]. Moscow: Fizkultura i sport Publ. (rus).

9. Reykovskiy, Ya. (1979). Eksperimentalnaya pskihologiya emotsiy [Experimental psychology of emotions]. Moscow: Progress Publ. (rus).

10. Simonov, P. V. (1981). Emotsionalnyy mozg [Emotional brain]. Moscow: Nauka Publ. (rus).

11. Chernikova, O. A. (1967). Issledovaniye emotsionalnoy ustoychivosti kak vazhneyshego pokazatelya psikhologicheskoy podgotovlennosti sportsmena $\mathrm{k}$ sorevnovaniyam [Investigation of emotional stability as the most important 
indicator of the athlete's psychological preparedness for competitions. Psikholo-gicheskiye voprosy sportivnoy trenirovki [Psychological questions of sports training]. Moscow: Fizkultura i sport Publ. (rus).

12. Ekman, P. (2003). Psikhologiya lzhi [Telling Lies]. St. Petersburg: Piter Publ. (rus).

13. Arnold, M. B. (1967). Stress and emotion. In M. H. Appley, \& R. Trumbull (Eds.). Psychological stress (pp. 123-140). New York: Appletin-Century Crofts.

14. Kang, S.-M., Day, J. D., Meara, N. M. (2005). Socialand emotional intelligence: Starting a conversation bout their similarities and differences. In R. Schulze, R. D. Roberts (eds). Emotional intelligence: An international handbook. Cambridge, MA: Hogrefe, pp. 91-105.

15. Malkhazov, A. (2008). New solutions to the problem of the psychological support of an operator's safety. Proceedings of the Second World Congress "Aviation in the XXI - st century" "Safety in aviation and space technology". Vol. 2. Kyiv, pp. 6.28-6.32.

16. Lebrecht, S., Bar, M., Feldman, B. L., \& Tarr, M. J. (2012). Micro-valences: Perceiving affective valence in everyday objects. Frontiers in Psychology, 3, 107.

\section{Malkhazov O. O. The Theoretical Framework of Emotional Resilience Studying}

Emotional resilience is defined as an integrative property of the individual, which is provided by a balanced dynamic interaction of single subsystems of the cyclic multilevel functional system of behavioral regulation, and determines the effectiveness of management and goal achievement in significant emotionogenic situations. There is analyzed the role of emotional experience in constructing the image of the needful future, as well as its influence on the individual's motivation and behavior. It was conducted the study of the influence of different groups of emotions on emotional resilience, for which the five-component typology of basal emotions was used. It is established that emotional resilience depends on the general alignment of the parameters of experience and activity types in which this experience was formed, and the attribution of this or that individual to a certain qualitative type of emotionality is not extrapolated to the level of his/her emotional stability. It was found that emotional resilience predetermines the choice of the suitable action plan (the image of a needful future) and the peculiarities of its direct realization (performance manner) and is determined both by experience with the included core representations and by the primary (superficial) representations - the forms of activity (and one of the factors usually prevails in a particular situation). It is concluded that emotional resilience clearly does not correlate with the intensity of negative feelings, although the latter are somewhat higher in the group of emotionally irresilient subjects.

Key words: activity, emotional resilience, rehabilitation measures, image of the needful future, performance manner.

(C) Малхазов О. P. 